\title{
First Report of Tomato chlorotic spot virus in the Non-Solanaceous Weeds Erect Spiderling (Boerhavia erecta), Asian Spiderflower (Cleome viscosa), and Sweet Chili Pepper (Capsicum chinense) in Puerto Rico
}

\begin{abstract}
Consuelo Estévez de Jensen, Agro-Environmental Sciences Department, University of Puerto Rico, Mayagüez, PR 00681; Ismael E. Badillo-Vargas, Texas A\&M AgriLife Research, Weslaco, TX 78596; Galen Frantz and H. Charles Mellinger, Glades Crop Care, Inc., Jupiter, FL 33458; William W. Turechek, USDA-ARS, Fort Pierce, FL 34945; Samuel F. Hutton, GCREC, University of Florida, Wimauma, FL 33598; Joseph E. Funderburk, NFREC, University of Florida, Quincy, FL 67891; Rayapati A. Naidu, IAREC, Washington State University, Prosser, WA 99350; and Scott Adkins, USDA-ARS, Fort Pierce, FL 34945
\end{abstract}

Accepted for publication 15 February 2017.

Tomato chlorotic spot virus (TCSV) has recently emerged in commercial plantings of several crops, including vegetables, ornamentals, and peanuts in the Caribbean and Florida (Adegbola et al. 2016; Batuman et al. 2014; Webster et al. 2015). In Puerto Rico, TCSV was detected in tomato (Solanum lycopersicum), bell pepper (Capsicum annuum), and jimsonweed (Datura stramonium) in late 2012 and early 2013 at the University of Puerto Rico's Juana Diaz Experiment Station and on commercial farms in Santa Isabel (Webster et al. 2013). In spring 2013, TCSV was detected in lettuce (Lactuca sativa) in Guayanilla (Estévez de Jensen and Adkins 2014).

From October 2015 through December 2016, observations of weeds at sites of previous outbreaks of TCSV in vegetables in Santa Isabel revealed chlorosis, necrosis, and distortion of young leaves of erect spiderling (Boerhavia erecta, family Nyctaginaceae, Fig. 1A and B) and chlorosis, mottling, and distortion of young leaves of Asian spiderflower (Cleome viscosa, known locally as plantanillo, family Capparaceae, Fig. 1C and D). Typical tospovirus symptoms - necrotic and chlorotic spots, and bronzing-were also observed on leaves of sweet chili pepper (Capsicum chinense, known locally as ají dulce, Fig. $1 \mathrm{E}$ and F) and tomato, along with stem and apical necrosis, and stunting, in these same areas. Sweet chili pepper plants developed symptoms within one month of transplanting and $\sim 45 \%$ of plants were symptomatic by three months.

Representative samples of all four plant species tested positive with Tomato spotted wilt virus (TSWV) lateral flow immunoassay reagents (Agdia, Elkhart, IN). A positive result with this assay is an indication of the presence of one or more tospoviruses since these reagents react with TSWV and several closely related tospoviruses including Groundnut ringspot virus (GRSV) and TCSV (Adkins et al. 2015). Twelve of 20 initial sweet chili pepper samples also tested positive with GRSV/TCSV enzyme-linked immunosorbent assay reagents (Agdia) in Puerto Rico, further indicating the presence of a tospovirus.

To identify the tospovirus present, 10 erect spiderling, 11 Asian spiderflower, an additional 13 sweet chili pepper, and six tomato

Corresponding authors: Consuelo Estévez de Jensen, E-mail: consuelo.estevez@upr. edu; and Scott Adkins, E-mail: scott.adkins@ars.usda.gov

This article is in the public domain and not copyrightable. It may be freely reprinted with customary crediting of the source. The American Phytopathological Society, 2017 (including transplant) samples collected between October 2015 and December 2016 were further analyzed in Florida as follows. Total RNA was extracted from representative symptomatic leaves of all samples using RNeasy Plant Mini Kit (Qiagen, Valencia, CA) and tested by RT-PCR with TCSV-specific nucleocapsid (N), movement protein (NSm), or RNA-dependent RNA polymerase (L) gene primers as previously described (Webster et al. 2015). Amplicons of the expected sizes were produced with all three TCSV primer sets from eight erect spiderling, seven Asian spiderflower, nine sweet chili pepper, and six tomato samples. Primers specific for the $\mathrm{N}$ gene of TSWV or GRSV (Webster et al. 2013) did not amplify products from any sample.

Three TCSV amplicons (N, NSm, and L) from two samples of each plant species were gel-purified and cloned (pGEM-T, Promega, Madison, WI). Five clones of each amplicon were sequenced in both directions and consensus sequences were deposited in GenBank (KY288655 to KY288667). All three genes had 95 to $100 \%$ nucleotide identity with all TCSV isolates in GenBank, including 99 to $100 \%$ nucleotide identity with previously characterized TCSV isolates from tomato, pepper, jimsonweed, and lettuce in Puerto Rico (Estévez de Jensen and Adkins 2014; Webster et al. 2013). Corresponding amplicons showed $99 \%$ nucleotide identity to each other across all plant species in this study.

In November 2016, thrips were collected from symptomatic erect spiderling, Asian spiderflower, sweet chili pepper, and tomato plants. Frankliniella schultzei, F. gossypiana, F. kelliae, Scirtothrips dorsalis, and Thrips palmi were identified in these samples. Frankliniella schultze $i$ was the only known TCSV vector found in erect spiderling, Asian spiderflower, and sweet chili pepper samples, similar to previous observations for other TCSV-infected plant species in Puerto Rico (Estévez de Jensen and Adkins 2014; Webster et al. 2013). However, with the exception of a single Asian spiderflower sample, $F$. schultzei was greatly outnumbered by $F$. gossypiana and/or $T$. palmi.

This is the first report of TCSV infection of erect spiderling, Asian spiderflower, and sweet chili pepper in Puerto Rico, although both weeds have been recently observed with TCSV infections in the Dominican Republic (Batuman et al. 2014). Collectively, these results suggest that multiple weed species may serve as reservoirs for TCSV and its thrips vector in Puerto Rico and elsewhere in the Caribbean. Given the continuing identification of new TCSV hosts, ecological and epidemiological studies should be pursued to improve our understanding of TCSV spread in this region. 

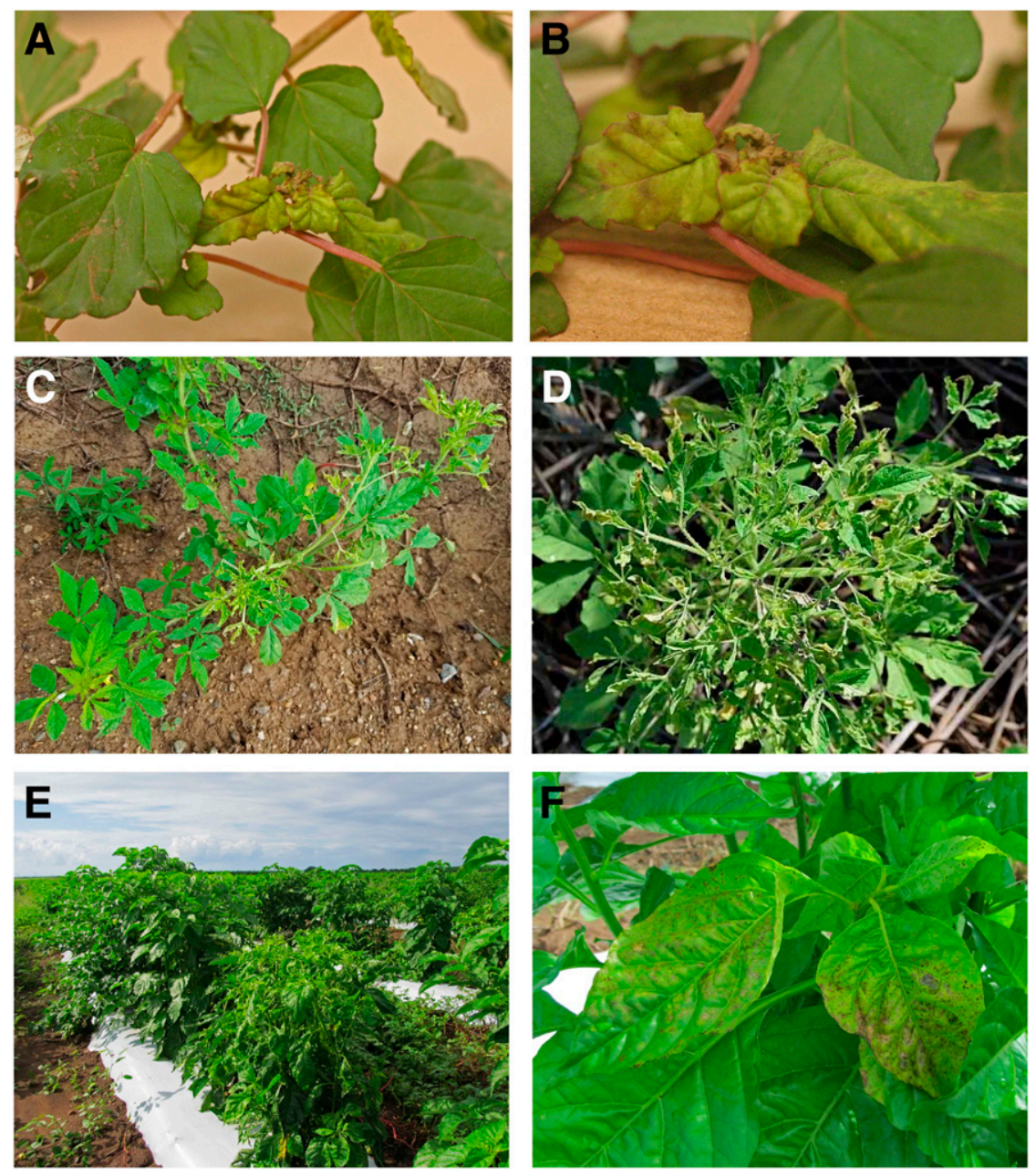

\section{FIGURE 1}

Symptoms of Tomato chlorotic spot virus infection of non-solanaceous weeds and sweet chili pepper in Puerto Rico. Foliar chlorosis, necrosis, and distortion of erect spiderling (A) especially apparent in young leaves (B) observed in October 2015. Foliar chlorosis, mottling, and distortion of Asian spiderflower (C) also most evident in young leaves (D) observed in November 2016. Stunting of sweet chili pepper plant (foreground) in field with many weeds between pepper beds (E), and necrotic spots on young sweet chili pepper leaves (F) observed in December 2016.

\section{Acknowledgments and Disclaimers}

The use of trade, firm, or corporation names in this publication is for the information and convenience of the reader. Such use does not constitute an official endorsement or approval by the United States Department of Agriculture or the Agricultural Research Service of any product or service to the exclusion of others that may be suitable. The research in this report was supported, in part, by USDA-AFRI CAP Grant 2012-68004-20166 and Florida Specialty Crop Block Grant 22901.

\section{Literature Cited}

Adegbola, R., Fulmer, A. M., Williams, B., Brenneman, T. B., Kemerait, R. C., Sheard, W., Woodward, J. E., Adkins, S., and Naidu, R. A. 2016. First report of the natural occurrence of Tomato chlorotic spot virus in peanuts in Haiti. Plant Dis. 100:1797.
Adkins, S., Webster, C. G., Mellinger, H. C., Frantz, G., Turechek, W. W., McAvoy, E., Reitz, S. R., and Funderburk, J. E. 2015. Detection and characterization of tomato viruses: A case study of emerging tospoviruses in Florida. Acta Hortic. 1069:83-85.

Batuman, O., Rojas, M. R., Almanzar, A., and Gilbertson, R. L. 2014. First report of Tomato chlorotic spot virus in processing tomatoes in the Dominican Republic. Plant Dis. 98:286.

Estévez de Jensen, C., and Adkins, S. 2014. First report of Tomato chlorotic spot virus in lettuce in Puerto Rico. Plant Dis. 98:1015.

Webster, C. G., Estévez de Jensen, C., Rivera-Vargas, L. I., Rodrigues, J. C. V., Mercado, W., Frantz, G., Mellinger, H. C., and Adkins, S. 2013. First report of Tomato chlorotic spot virus in tomato, pepper and jimsonweed in Puerto Rico. Plant Health Prog. 10.1094/PHP-2013-0812-01-BR

Webster, C. G., Frantz, G., Reitz, S. R., Funderburk, J. E., Mellinger, H. C., McAvoy, E., Turechek, W. W., Marshall, S. H., Tantiwanich, Y., McGrath, M. T., Daughtrey, M. L., and Adkins, S. 2015. Emergence of Groundnut ringspot virus and Tomato chlorotic spot virus in vegetables in Florida and the southeastern United States. Phytopathology 105:388-398. 